\title{
QUALITY OF IRRIGATED APPLES IN THE SEMIARID REGION OF THE NORTHEAST OF BRAZIL ${ }^{1}$
}

\author{
CÍNTIA PATRÍCIA MARTINS DE OLIVEIRA ${ }^{2 *}$, WELSON LIMA SIMÕES ${ }^{3}$, JOSÉ ALIÇANDRO BEZERRA SILVA ${ }^{2}$, \\ PAULO ROBERTO COELHO LOPES ${ }^{3}$, JOSTON SIMÃO ASSIS ${ }^{3}$
}

\begin{abstract}
The great solar radiation in the Brazilian semiarid region, combined with an adequate irrigation management, favors fruit production and quality of crops that were adapted to this region. The objective of this work was to evaluate the fruit quality of two apple cultivars grown in the Sub-Mid São Francisco River Valley under different irrigation water depths. A complete randomized block experimental design in a split-plot arrangement with five replications was used. The plots consisted of four irrigation water depths (ID) (60, 80, 100 and $120 \%$ of the reference evapotranspiration - ETo), the subplots consisted of two apple cultivars (C) (Julieta and Princesa) and the sub-subplots consisted of fruit positions in the tree canopies (FP) (east and west sides). The soluble solids content (SS), titratable acidity (TA), SS/TA ratio, pulp firmness (PF) and fresh weight $(\mathrm{FW})$ of the fruits were evaluated. The factors evaluated showed no triple interaction between the evaluated factors, however, the SS and TA were significantly affected by them; the interaction between ID and $\mathrm{C}$ significantly affected the PF; the interaction between ID and FP significantly affected the PF, SS/TA ratio and FW; and the interaction between $\mathrm{C}$ and FP significantly affected the SS/TA ratio. The increase in water depth increased the fruit size of both cultivars, without compromising the post-harvest quality. The cultivar Princesa presented the best results regarding SS, TA, PF and FW, however, both cultivars had organoleptic characteristics within the recommended standards for commercialization. The fruits harvested on the west side presented better post-harvest quality.
\end{abstract}

Keywords: Water regimen. Malus domestica Borkh. Post-harvest.

\section{QUALIDADE DOS FRUTOS DE MACIEIRAS IRRIGADAS NO SEMIÁRIDO NORDESTINO}

RESUMO - A elevada radiação associada ao manejo adequado da irrigação no semiárido brasileiro favorece o aumento da produção e a qualidade dos frutos de culturas adaptadas a região. O objetivo deste trabalho foi avaliar a qualidade dos frutos de duas variedades de maçãs cultivadas na região do Vale Submédio do Rio São Francisco sobre diferentes lâminas de irrigação. O delineamento experimental foi em blocos ao acaso, com parcelas subsubdivididas, com cinco repetições, sendo as parcelas principais quatro lâminas de irrigação (60; 80; 100; e 120 \% da evapotranspiração de referência - ETo), as subparcelas duas cultivares de maçã (Julieta e Princesa) e as subsubparcelas as posições da copa da planta (leste e oeste). Avaliou-se o teor de sólidos solúveis (SS), a acidez titulável (AT), a relação entre SS/AT, a firmeza de polpa (FP) e a massa de matéria fresca do fruto (MMFF). Não se observou interação tripla entre os fatores avaliados, mas houve um efeito significativo das características SS e AT, da interação entre lâminas e cultivares para FP, da interação entre lâminas e posição para FP, razão de SS/AT e MMFF e da interação entre cultivares e posição para relação SS/AT. O aumento da irrigação promoveu aumento do tamanho dos frutos, das duas cultivares, sem comprometer a qualidade pós-colheita. A cultivar Princesa apresentou os melhores resultados quanto o SS, AT, FP e MMFF, contudo ambas as cultivares apresentaram características organolépticas dentro do recomendado para comercialização. Os frutos colhidos do lado oeste apresentaram melhor qualidade pós-colheita.

Palavras-chave: Regime hídrico. Malus domestica Borkh. Pós-colheita.

\footnotetext{
*Corresponding author

${ }^{1}$ Received for publication in $05 / 04 / 2016$; accepted in $11 / 18 / 2016$.

Paper extracted from the master's thesis of the first author.

${ }^{2}$ Agricultural Engineering Post-Graduation Department, Universidade Federal do Vale do São Francisco, Juazeiro, BA, Brazil; cintiamartins.agr@gmail.com, alissandrojbs@gmail.com.

${ }^{3}$ Empresa Brasileira de Pesquisa Agropecuária, Petrolina, PE, Brazil; welson.simoes@embrapa.br, paulo.roberto@embrapa.br, joston.assis@embrapa.br.
} 


\section{INTRODUCTION}

The apple tree is from temperate climates and presents dormancy of buds, requiring a certain number of hours of cold weather $\left(<7.2^{\circ} \mathrm{C}\right)$ to the opening of its buds (PETRI; LEITE, 2008). However, new cultivars that need less hours of cold weather have been developed through breeding programs and launched in the market, such as the cultivars Princesa, which requires $350-450$ and the cultivar Julieta, which requires 300-450 hours of cold weather for natural overcoming of dormancy (LOPES; OLIVEIRA; SARMENTO, 2013).

The cultivar Princesa, which is used as a pollinator, has attractive medium-sized fruits, round-conical shape, red-brindle coloring, cream-white, crisp, firm, juicy pulp and semi-acidic flavor. The cultivar Julieta presents fruits with good commercial aspects, with average weight over 150 grams, and sweet, slightly acidic taste (LOPES; OLIVEIRA; SARMENTO, 2013).

Studies have shown the feasibility of producing apple cultivars that require short time of cold weather in the semiarid conditions of the São Francisco River Valley (LOPES et al., 2012; LOPES et al., 2013; OLIVEIRA et al., 2013). Technically more extensive works, aiming to improve the cultivation of this species, may contribute to the crop diversification in irrigated areas of the Northeast of Brazil, and to the availability of fruits at times different from the traditional production regions (OLIVEIRA et al., 2013).

According to Conceição (2010), the maintenance of an adequate water condition in the soil is essential to obtain high yields and quality fruits. Several studies report the positive effect of proper use of irrigation on apple yield and quality (MPELASOKA; BEHBOUDIAN; DIXON, 2000; LEIB et al., 2006; MOHAWESH ; AL-ABSI, 2009).

However, it is the combination of physical attributes (diameter, weight and epidermis color) with intrinsic attributes (soluble solids content, titratable acidity and their ratio) that ensures a greater acceptability of the fruit by the consumer (CHITARRA; CHITARRA, 2005). Thus, apples with better physical and chemical characteristics are selected for the domestic market and export, and those with low quality for fresh consumption are directed to processing industries.

Considering the apple tree adaptability to irrigated areas of the semi-arid region of Northeast of Brazil, the objective of this work was to evaluate the fruit quality of two apple cultivars grown in the Sub-Mid São Francisco River Valley under different irrigation water depths.

\section{MATERIAL AND METHODS}

The experiment was conducted in the experimental orchard of the Corcino Frutas Farm, which is located in the Sector 5 of the Irrigated Perimeter Senator Nilo Coelho, Petrolina, State of Pernambuco (PE), Brazil. The apple trees (Malus domestica) evaluated were two years old, and propagated by grafting (Maruba rootstock with M9 filter) and grown spaced 4.0x1.25 m apart.

A complete randomized block experimental design in a split-plot arrangement with five replications was used. The plots consisted of four irrigation water depths $(60,80,100$ and $120 \%$ of the reference evapotranspiration - ETo), the subplots consisted of two apple cultivars (Julieta and Princesa) and the sub-subplots consisted of fruit positions in the tree canopies (east and west sides).

A two-line drip irrigation system was used, with flow of $2.1 \mathrm{~L} \mathrm{~h}^{-1}$ per emitter and daily irrigation. The irrigation water depths were determined based on the ETo, using the Penman-Monteith method and meteorological data of the experimental period from a weather station near to the experimental site (Figure 1).

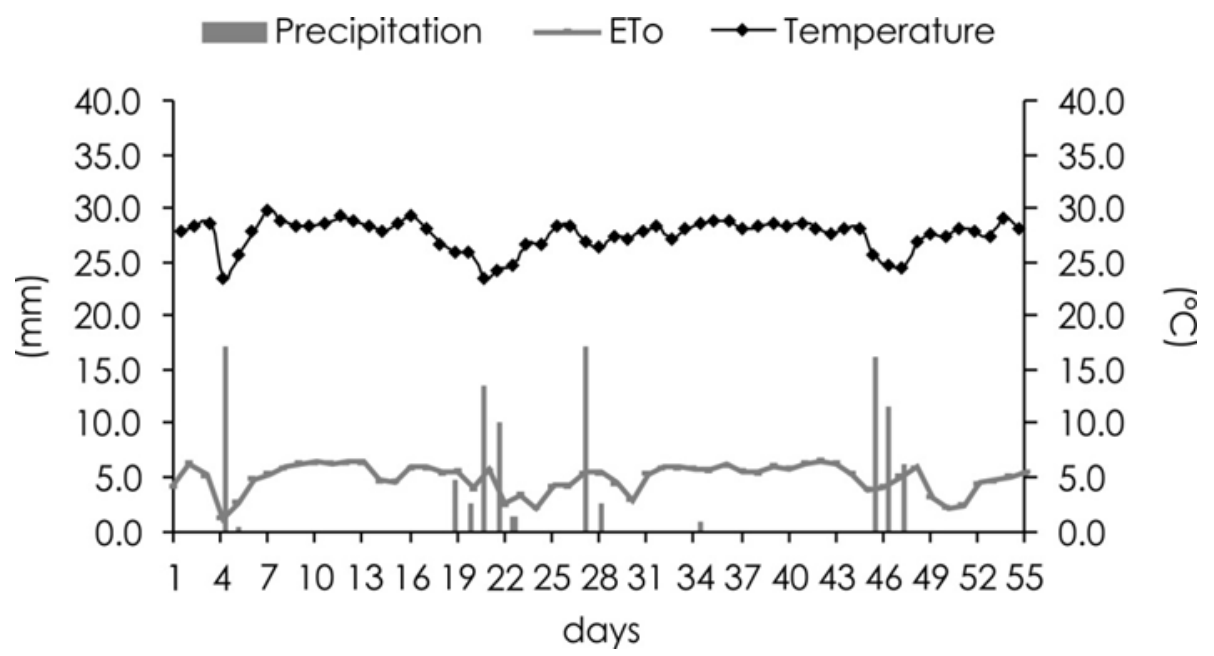

Figure 1. Mean temperature $\left({ }^{\circ} \mathrm{C}\right)$, reference evapotranspiration $(\mathrm{ETo})$ and precipitation $(\mathrm{mm})$ during the experimental period. Petrolina PE. 
The evaluations of the fruits were carried out during the harvest of the 2014-2015 crop season, from early February to early March.

Fruits at commercial maturity were harvested, packed in plastic bags and evaluated at the Embrapa Semi-Arid Post-Harvest Laboratory. Ten fruits of each treatment were randomly selected, representing ten replications. The soluble solids (SS), titratable acidity (TA), SS/TA (ratio), pulp firmness (PF) and fresh weight (FW) of the fruits were determined. The analyzes were performed according to the methodology described by the Instituto Adolfo Lutz (1985).

The results were subjected to analysis of variance, evaluating the interaction between the factors. The statistically significant means were compared by the Tukey test (qualitative factors) and regression analysis (quantitative factors) at 5\% of probability of error, using the statistical program SAS (SAS INSTITUTE, 2002).

\section{RESULTS AND DISCUSSION}

The statistical analysis showed no triple interaction between the evaluated factors, however, the soluble solids (SS) and titratable acidity (TA) were significantly affected by them; the interaction between irrigation water depths (ID) and cultivars (C) significantly affected the pulp firmness (PF); the interaction between ID and fruit position (FP) significantly affected the PF, SS/TA ratio and fresh weight (FW) of the fruits; and the interaction between $\mathrm{C}$ and FP significantly affected the SS/TA ratio (Table 1).

Table 1. Analysis of variance of variables related to post-harvest quality of apple (Malus domestica Borkh) fruits depending on the cultivar, fruit position in the tree canopy and irrigation water depth.

\begin{tabular}{|c|c|c|c|c|c|c|}
\hline \multirow{2}{*}{$\begin{array}{c}\text { Source } \\
\text { of Variation }\end{array}$} & \multirow{2}{*}{$\begin{array}{l}\text { Degrees } \\
\text { of Freedom }\end{array}$} & \multicolumn{5}{|c|}{$F$ test } \\
\hline & & SS & TA & $\mathrm{SS} / \mathrm{TA}$ & $\mathrm{PF}$ & $\mathrm{FW}$ \\
\hline Block (B) & 4 & 0.03 & 0.001 & 11.05 & 15.51 & 18.13 \\
\hline Water Depth (WD) & 3 & $2.75^{*}$ & $0.019 *$ & $206.65^{\text {ns }}$ & $678.11^{\mathrm{ns}}$ & $922.19^{\mathrm{ns}}$ \\
\hline WD $\times$ B & 12 & - & - & - & - & - \\
\hline Cultivar (C) & 1 & $63.32 *$ & $0.29 *$ & $407.53^{\mathrm{ns}}$ & $564.59^{\mathrm{ns}}$ & $2604.49^{\mathrm{ns}}$ \\
\hline $\mathrm{C} \times \mathrm{WD}$ & 3 & $0.2^{\mathrm{ns}}$ & $0.001^{\mathrm{ns}}$ & $44.16^{\mathrm{ns}}$ & $41.68^{*}$ & $218.81^{*}$ \\
\hline$C \times W D \times B$ & 16 & - & - & - & - & - \\
\hline Fruit position (FP) & 1 & $0.73 *$ & $0.000^{\mathrm{ns}}$ & $5.01^{\mathrm{ns}}$ & $18.87^{\mathrm{ns}}$ & $44.11^{\mathrm{ns}}$ \\
\hline FP $x$ WD & 3 & $0^{\text {ns }}$ & $0.003^{\mathrm{ns}}$ & $19.19^{*}$ & $29.84 *$ & $11.19^{\text {ns }}$ \\
\hline $\mathrm{FP} \times \mathrm{C}$ & 1 & $0.11^{\mathrm{ns}}$ & $0.005^{\mathrm{ns}}$ & $61.07 *$ & $29.41^{\mathrm{ns}}$ & $3.14^{\mathrm{ns}}$ \\
\hline FP $x \mathrm{C} \times \mathrm{WD}$ & 3 & $0.29^{\mathrm{ns}}$ & $0.003^{\mathrm{ns}}$ & $12.91^{\mathrm{ns}}$ & $22.38^{\mathrm{ns}}$ & $29.88^{\text {ns }}$ \\
\hline CV (\%) & & 2.42 & 8.3 & 9.5 & 3.86 & 9.1 \\
\hline
\end{tabular}

SS $=$ Soluble Solids; TA $=$ Titratable Acidity; SS $/ \mathrm{TA}=$ Soluble Solids to Titratable Acidity ratio; PF $=$ Pulp Firmness; FW $=$ Fruit Fresh Weight; ${ }^{\mathrm{ns}}=$ Not significant; $*=$ Significant at $5 \%$ by the $\mathrm{F}$ test.

The SS of the cultivars evaluated was significantly different, with greater contents in the cultivar Princesa (14.2\%) compared with the cultivar

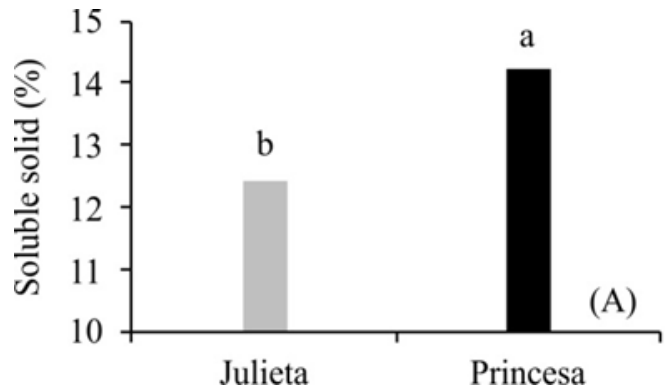

Julieta (13.8\%) (Figure 2A). The fruits in the western position presented higher contents of SS (13.4\%) than those on the east side (13.2\%) (Figure 2B).

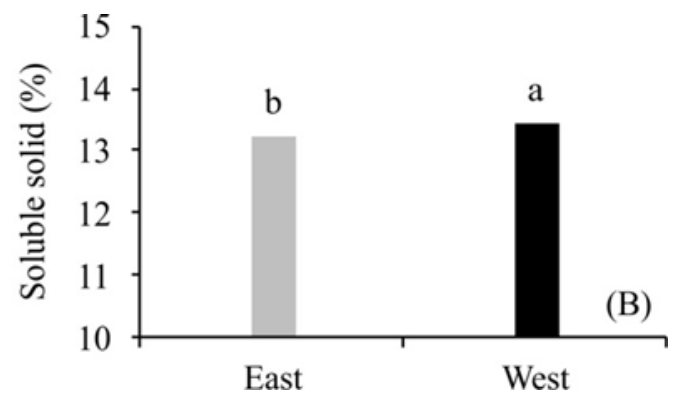

Figure 2. Soluble solid contents of apple (Malus domestica Borkh) fruits grown in the Sub-Mid São Francisco River Valley depending on the cultivar (A) and fruit position in the tree canopy (B). 
Santos, Hickel and Argenta (2015) evaluated apples grown in southern Brazil and found SS values of about $14 \%$, which were similar to the result found in the present study. Santos et al. (2010) evaluated apple cultivars under irrigation in the Sub-Mid São Francisco River Valley and also found a similar SS value $(14.2 \%)$ for the cultivar Princesa. However, Chagas et al. (2012), assessed quality attributes of apple trees under subtropical conditions and found a SS content for the cultivar Princesa of $12.2 \%$, which was below that found for this cultivar in the present study.

The SS content varies mainly when comparing different species, cultivars, maturation stages and climates, ranging from 2 to $25 \%$, with average values between 8 and 14\% (CHITARRA; CHITARRA, 2005). Thus, the cultivars evaluated presented SS contents within the recommended range for acceptability of the fruit by the consumer.

Feliciano et al. (2010) also reported that sugar content in apples may also vary depending on the fruit position in the tree canopy. Fruits exposed to the sun tend to present higher sugar contents than those in shaded parts of the trees, confirming the results found in the present study.

According to Rizzon et al. (2005), factors related to photosynthetic activity such as radiation and soil moisture affect the sugar production and accumulation, thus altering the SS content.

However, the response curve of photosynthesis to the increase in radiation is hyperbola in fruit trees, saturating with values of 600 to $1200 \mu \mathrm{mol} \mathrm{m} \mathrm{m}^{-2} \mathrm{~s}^{-1}$, i.e., about half of the maximum intensity of the photosynthetically active photon flux that reaches the soil (DOMINGOS, 2009). The fruits on the west side of the tree canopies presented greater accumulation of soluble solids, which was probably due to a greater efficiency of photosynthetic activity of leaves in this position.

The SS contents found in the apple fruits decreased with the increasing water depths. The SS content found for the water depth of $60 \%$ ETo $(13.8 \%)$ was higher than those found for the water depth of $120 \%$ ETo (12.9\%) (Figure 3).

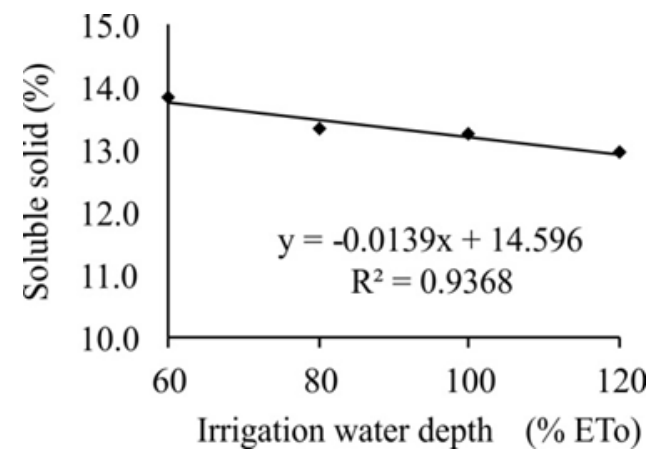

Figure 3. Soluble solids contents of apple fruits grown in the Sub-Mid São Francisco River Valley depending on irrigation water depths.

The SS content of the apples increased with decreasing water depths. Similar result was found by Leib et al. (2006) in semiarid climatic conditions in Washington State, USA.

The increase of SS content in the fruits increased their dry matter. Mpelasoka, Behboudian and Green (2001) assessed the apple yield and quality responses to irrigation and found increases in $\mathrm{SS}$ contents followed by increases in dry matter.

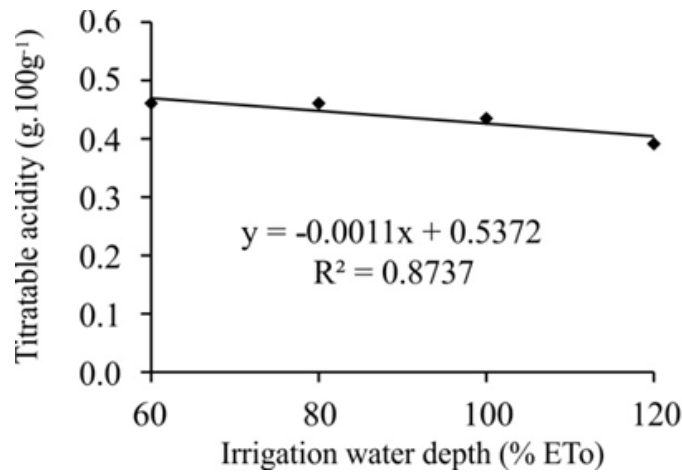

The water depths affected the titratable acidity of the apple pulps (Figure 4A), with data fitting to the negative linear model. The cultivars showed significant differences in fruit acidity (Figure 4B), denoting the lower acidity of the cultivar Julieta, compared with the cultivar Princesa. This result may be due to differences between the genotypes studied.

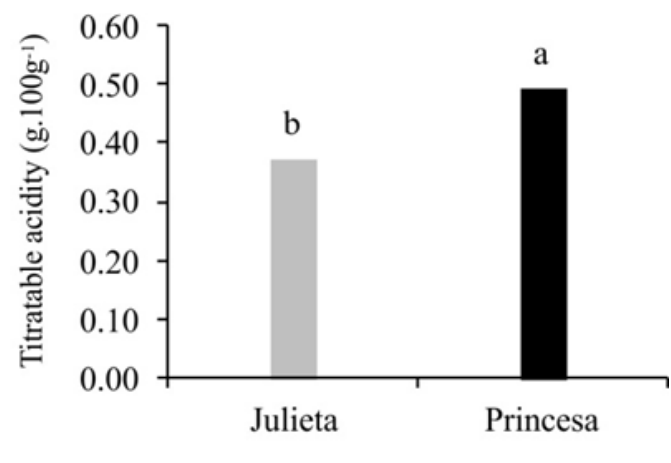

Figure 4. Titratable acidity (A) of apple (Malus domestica Borkh) fruits, grown in the Sub-Mid São Francisco River Valley, depending on irrigation water depths and cultivars. 
The greatest content of malic acid, which determines the TA, was found in fruits irrigated with $60 \%$ ETo, differing significantly from the contents found in fruits irrigated with $120 \%$ ETo. Mohawesh and Al-Absi (2009) assessed the physiological response of two apple genotypes to different water regimes in the semi-arid region of Jordan and observed a decrease in TA with increasing irrigation, which confirms the results found in the present study.

The irrigation water depth decrease probably decreased the turgidity of leaf guard cells, causing stomatal closure (TAIZ; ZEIGER, 2013). This process is caused by changes in the photosynthetic activity, synthesis rate and translocation of assimilates in the apple trees, which may have

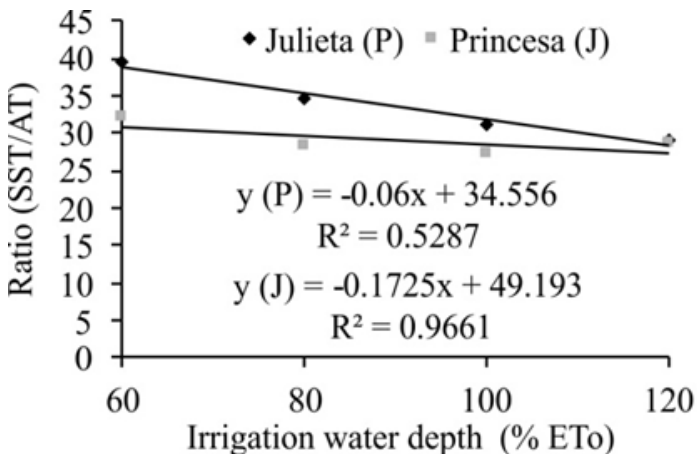

affected the qualitative attributes of the fruits, i.e., the soluble solid contents and titratable acidity increased with decreasing water depths.

According to Vieira et al. (2009), the usual titratable acidity of commercial fruits in southern Brazil ranges from 0.20 to $0.41 \mathrm{~g}$ of malic acid per 100 g. Chagas et al. (2012), compared apple cultivars in eastern São Paulo State and found the cultivar Princesa with $0.50 \mathrm{~g}$ of acid malic per $100 \mathrm{~g}$, which was similar to that found in the present study.

The interaction between water depths and cultivars significantly affected the SS/TA ratio (Figure 5A), with the cultivar Julieta presenting greater contents, except comparing the values with irrigation of $120 \%$ ETo.

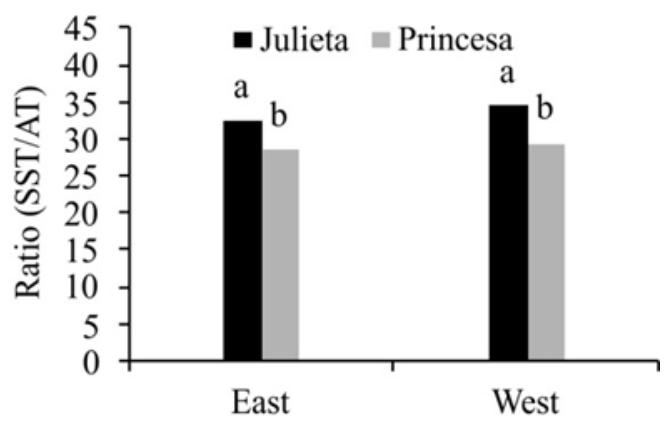

Figure 5. Soluble solids to titratable acidity ratio (SS/TA) of the apple (Malus domestica Borkh) cultivars Julieta and Princesa, grown in the Sub-Mid São Francisco River Valley, depending on the irrigation water depths (A) and fruit positions in the tree canopy (B).

According to the regression analysis, the SS/TA values increased linearly with decreasing water depths, with a significant difference in SS/TA ratio between the cultivars Julieta $(40 \%)$ and Princesa $(32 \%)$ in the water depth of $60 \%$ ETo (Figure 5A). Santos et al. (2010) found similar values for irrigated cultivar Princesa in semi-arid conditions in Brazil.

The mean SS/TA ratio of the cultivars depending on the fruit position in the tree canopy (Figure 5B) was 33\% (Julieta) and 29\% (Princesa), with the fruits on the west side of the tree canopies presenting the greatest SS and TA.

The increase of SS/TA ratio with decreasing water depths may be related to stress conditions, since several physiological processes are affected under advanced stages of water deficit, including the increase of respiratory rates (TURNER, 1997). The malic acid and sugars are used as substrates for the respiratory metabolism (ARGENTA, 2006), thus the increase of the sugar/acid ratio is related to the consumption rate of malic acid, which is greater than the consumption rate of sugars during maturation.

According to Wu et al. (2007), apple cultivars with SS/TA ratio lower than 20 are more suitable for industrial processing (juices and ciders), and those higher than 20 are considered sweet and suitable for fresh consumption. The cultivars studied presented values higher than 20 (sweet cultivars). Similar results were found in apples in southern Brazil (VIEIRA et al., 2009).

According to the regression analysis, the pulp firmness (PF) decreased linearly with increasing water depths (Figure 6). The depth of $60 \%$ ETo resulted in fruits with greater pulp firmness. The pulp firmness of the cultivars varied from 75 to $79 \mathrm{~N}$ (Figure 6A), presenting values near $77 \mathrm{~N}$ in fruits from both positions evaluated (Figure 6B).

The cultivar Princesa presented greater firmness, differing significantly from cultivar Julieta. This result was expected, since the cultivar Princesa usually presents fruits of more crisp and firm pulp (LOPES; OLIVEIRA; SARMENTO, 2013). According to Chitarra and Chitarra (2005), pulp firmness may vary mainly due to the regional climatic conditions, fruit position in the tree canopy and degree of maturation.

According to Mpelasoka Behboudian and Green (2001), the increasing pulp firmness with decreasing water depths is due to the production of smaller fruits by the plants in soils with low moisture, confirming the results of the present study. 

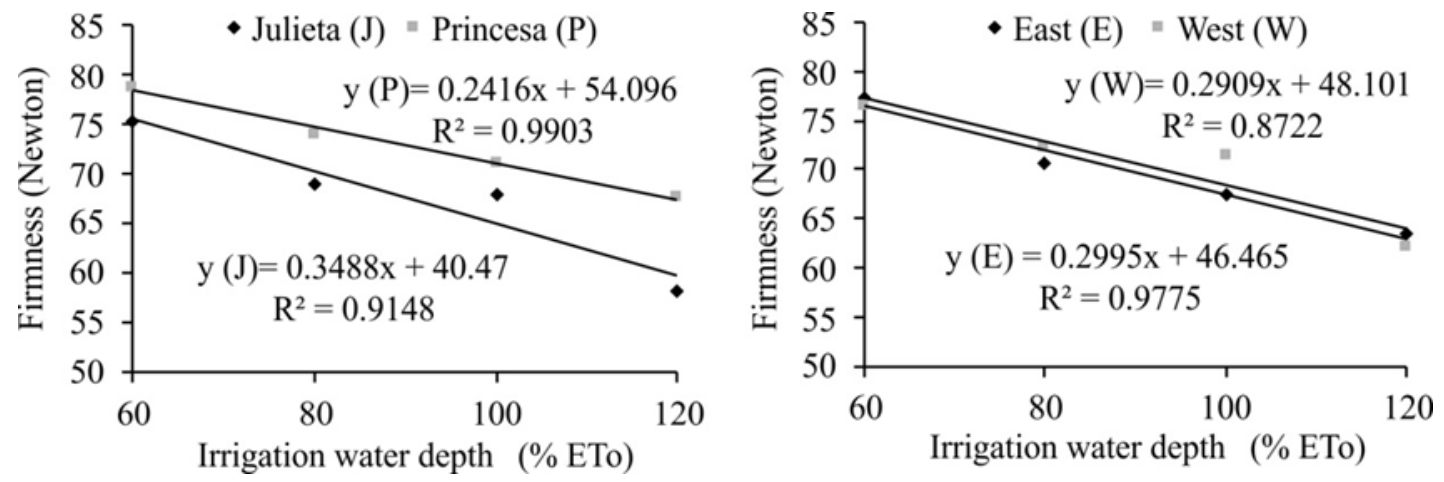

Figure 6. Pulp firmness of apples (Malus domestica Borkh) grown in the Sub-Mid São Francisco River Valley depending on the interaction between irrigation water depths and cultivars (A) and the interaction between irrigation water depths and fruit positions in the tree canopy (B).

The minimum limit of pulp firmness in southern Brazil is divergent in the literature, however, when the pulp firmness approaches $50 \mathrm{~N}$, the risk of damages to apples during the commercialization increases. Fruits that need to be stored for long periods are usually harvested with pulp firmness higher than $70 \mathrm{~N}$. Thus, the pulp firmness of the apples evaluated was within the recommended values for commercialization and storage, especially the fruits in the western position.

The fruit fresh weight (FW) was lower with the water depth of $60 \%$ ETo, which statistically differed from the depth of $120 \%$ ETo (Figure 7). The final fruit size decrease is one of the most consistently reported effects of reducing irrigation in apples (MPELASOKA; BEHBOUDIAN; DIXON, 2000; LEIB et al., 2006; MOHAWESH; AL-ABSI, 2009).

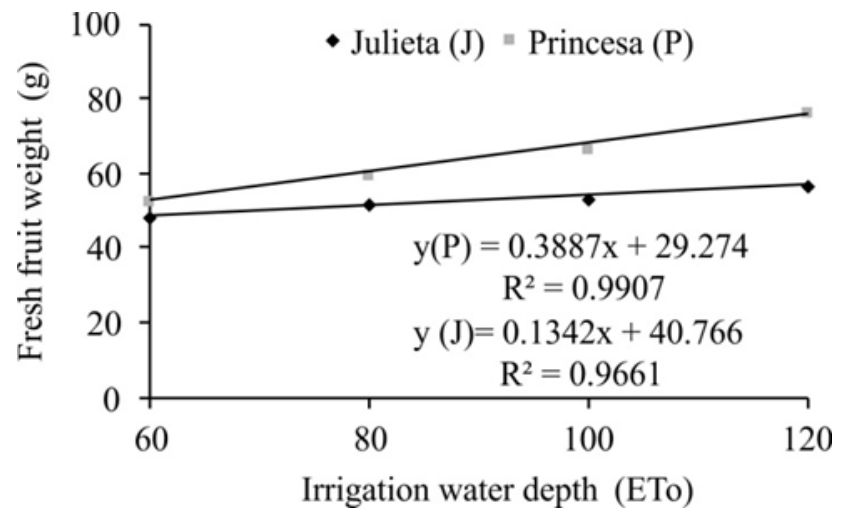

Figure 7. Fresh fruit weight (FW) of the apple (Malus domestica Borkh) cultivars Julieta and Princesa, grown in the Sub-Mid São Francisco River Valley, depending on irrigation water depths.

According to Yao, Neilsen and Neilsen (2001), the reducing of irrigation water depths in apple orchards, especially in the phases 2 (cell elongation) and 3 (maturation), tends to decrease the crop yield due to the reduction of number, size and weight of fruits.

The cultivar Princesa had higher FW than the cultivar Julieta in all water depths (Figure 7). This result may be related to the better use of available water by the genotype Princesa. The values of FW ranged from 48.52 to $57.26 \mathrm{~g}$ (Julieta) and from 53.22 to 76.84 (Princesa).

Similar results were found by Oliveira et al. (2014), who evaluated eight apple cultivars that require short time of cold weather. On the other hand, some studies on mild winter regions showed higher FW means for the cultivar Princesa, differing from the results in the present study (SANTOS et al., 2010; (CHAGAS et al., 2012).

\section{CONCLUSIONS}

The largest irrigation water depth evaluated $(120 \% \mathrm{ETo})$ is recommended for production of large fruits without compromising their post-harvest commercial quality.

The apple cultivars Princesa and Julieta produced in the Brazilian semiarid presented fruits within the standards required for commercialization and are suitable for fresh consumption.

\section{REFERENCES}

ARGENTA, L. C. Fisiologia pós-colheita: maturação, colheita e armazenagem dos frutos. In: EMPRESA DE PESQUISA AGROPECUÁRIA EXTENSÃO RURAL DE SANTA CATARINA. A cultura da macieira. Florianópolis: Empresa de 
Pesquisa Agropecuária e Extensão Rural de Santa Catarina, 2006. v. 1, cap. 20, p. 691-732

CHAGAS, E. A. et al. Production and quality attributes of apple tree cultivars in subtropical conditions at eastern of São Paulo state. Ciência Rural, Santa Maria, v. 42, n. 10, p. 1764-1769, 2012.

CHITARRA, M. I. F.; CHITARRA, A. B. Pós-colheita de frutas e hortaliças: fisiologia e manuseio. 2. ed. Lavras, MG: UFLA, 2005. 785 p.

CONCEIÇÃO, M. A. F. Balanço hídrico em fruteiras. Bento Gonçalves, RS: Embrapa Uva e Vinho, 2010. 12 p. (Embrapa Uva e Vinho. Circular Técnica, 82).

DOMINGOS, S. N. G. O Ensombramento como técnica de monda na macieira 'Gala' (Malus domestica Borkh.). 2009. 103 f. Dissertação (Mestrado em Engenharia Agronômica: Área de Hortofruticultura e Viticultura) - Universidade Técnica de Lisboa, Instituto Superior de Agronomia, Lisboa, 2009.

FELICIANO, R. $\mathrm{P}$ et al. Characterization of traditional and exotic apple varieties from Portugal. Part 1: nutritional, phytochemical and sensory evaluation. Journal of Functional Foods, Amsterdam, v. 2, n. 1, p. 35-45, 2010.

INSTITUTO ADOLFO LUTZ. Métodos químicos e físicos para análise de alimentos. 3. ed. São Paulo, SP: Normas analíticas do Instituto Adolfo Lutz, $1985,553 \mathrm{p}$.

LEIB, B. et al. Partial rootzone drying and deficit irrigation of 'Fuji' apples in a semi-arid climate. Irrigation Science, Berlim, v. 24, n. 2, p. 85-99, 2006.

LOPES, P. R. C. et al. Caracterização fenológica, frutificação efetiva e produção de maçãs 'Eva' em clima semiárido no nordeste brasileiro. Revista Brasileira de Fruticultura, Jaboticabal, v. 34, n. 4, p. 1277-1283, 2012.

LOPES, P. R. C.; OLIVEIRA, I. V. M.; SARMENTO, D. H. A. Avanços na produção de frutas de clima temperado no Estado do Ceará. In: SEMANA INTERNACIONAL DA FRUTICULTURA E AGROINDÚSTRIA, 20; AGROFLORES, 15., 2013. Fortaleza. Anais... Fortaleza: Instituto Frutal, 2013. 1 CD-ROM.

LOPES, P. R. C. et al. Growing Princesa apples under semiarid conditions in northeastern Brazil. Acta Scientiarum. Agronomy, Maringá, v. 35, n. 1, p. 93-99, 2013.
MPELASOKA B. S.; BEHBOUDIAN M. H.; DIXON J.; et al. Improvement of fruit quality and storage potential of 'Braeburn' apple through deficit irrigation. Journal of Horticultural Science and Biotechnology, Oxford, v.75, p.615-621, 2000.

MPELASOKA, B.; BEHBOUDIAN, M.; GREEN, S. Water use, yield and fruit quality of lysimeter-grown apple trees: responses to deficit irrigation and to crop load. Irrigation Science, Berlim, v. 20, n. 3, p. 107-113, 2001

MOHAWESH, O. E.; AL-ABSI, K. M. Physiological response of two apple genotypes to different water regimes under semiarid conditions. Scientia Horticulturae, v. 23, n. 3, p. 158-165, 2009.

OLIVEIRA, I. V. M. et al. Caracterização fenológica e frutificação efetiva de macieiras 'daiane' sob condições semiáridas no nordeste do Brasil. Revista de Ciências Agroambientais, Alta Floresta, v. 11, n. 2, p. 153-158, 2013.

OLIVEIRA, D. L. et al. Características físico-químicas de cultivares de macieiras pouco exigentes em frio. Revista Ceres, Viçosa, v. 61, n. 2, p. 284-287, 2014.

PETRI, J. L.; LEITE, G. B. Macieira. Revista Brasileira de Fruticultura, Jaboticabal, v. 30, n. 4 , p. $857-1166,2008$.

RIZZON, L. A.; BERNARDI, A. L.; MIELE, A. Características analíticas dos sucos de maçã Gala, Golden Delicius e Fuji. Ciência e Tecnologia de Alimentos, Campinas, v. 25, n. 4, p. 750-756, 2005.

SANTOS, A. C. B. et al. Caracterização físico-qumica de cinco cultivares de maçã produzidas sob irrigação no Submédio São Francisco. In: CONGRESSO BRASILEIRO DE FRUTICULTURA, 21., 2010, Natal. Anais... Natal: SBF, 2010.

SANTOS, J. P. D.; HICKEL, E. R.; ARGENTA, L. C. Effects of bagging on apple fruits quality under different development stages. Revista Brasileira de Fruticultura, Jaboticabal, v. 37, n. 3, p. 667-675, 2015

SAS INSTITUTE. Getting started with the SAS learning edition. Cary: SAS, 2002, 200 p.

TAIZ, L.; ZEIGER, E. Fisiologia Vegetal. 5. ed. Porto Alegre, RS: ARTMED, 2013. 918 p.

TURNER, N. C. Further progress in crop water relations. Advances in Agronomy, Newark, v. 58, n. 1, p. 293-325, 1997. 
VIEIRA, F. G. K. et al. Physico-chemical and antioxidant properties of six apple cultivars (Malus domestica Borkh) grown in southern Brazil. Scientia Horticulturae, Amsterdam, v. 122, n. 3, p. 421-425, 2009.

WU, J. et al. Chemical compositional characterization of some apple cultivars. Food Chemistry, Reading, v. 103, n. 1, p. 88-93, 2007.

YAO, S.; NEILSEN, G. H.; NEILSEN, D. Effects of water stress on growth and mineral composition of 'Gala' apple fruit. Acta Horticulturae, Leuven, v. 564, n. 56, p. 449-456, 2001. 